\title{
Development of Haploid and Double Haploid in Fruit Crops - A Review
}

\author{
Antara Das ${ }^{1,2 *}$, Kuldeep Kumar ${ }^{1}$, Kishor U. Tribhuvan ${ }^{1}$, \\ Swosti Suvadarshni Das ${ }^{2}$ and Maneesh Mishra ${ }^{2}$
}

\author{
${ }^{1}$ National Research centre On Plant Biotechnology, ICAR, New Delhi, India \\ ${ }^{2}$ Central Institute for Subtropical Horticulture, Luckhnow, Uttar Pradesh, India
}

\begin{tabular}{|l|l|l|l|l}
\hline \multicolumn{2}{c}{ A B S T R A C T } \\
\cline { 2 - 2 } $\begin{array}{l}\text { Keywords } \\
\text { Haploid, Double }\end{array}$ & $\begin{array}{l}\text { Homozygosity at a particular locus is always desirable feature for crop improvement } \\
\text { programs. Breeding is one of the approaches to attain this but it requires minimum 6-7 } \\
\text { cropping years. Due to this limitation it is only feasible in annuals. As most of the fruit } \\
\text { crops are not annuals, they grow in vegetative phase for 5-6 year before flowering to come. } \\
\text { Hence, to achieve homozygosity through breeding approaches is not feasible in them. Use } \\
\text { of haploid to produce double haploid is one of the potent approaches to overcome this } \\
\text { lacuna. Haploid can be either produce through androgenesis or gynogenesis, androgenesis } \\
\text { being most used approach. Here we review the applications of haploid and double haploid } \\
\text { production in fruit crops. }\end{array}$ \\
\hline $\begin{array}{l}\text { Accepted: } \\
\text { Available Online: } \\
10 \text { May 2018 }\end{array}$ &
\end{tabular}

\section{Introduction}

The term haploid refers to those plants which have gametophytic number of chromosome as compared to the sporophytes from which they have been developed. Spontaneously in natures they are produced through the process of apomixes and parthenogenesis (i.e. from an unfertilied egg).

Looking at the wide and unevitable application of diploids in crop development and improvement many new artificial strategies to develop haploids such as through distant hybridization, chemical treatment, $\mathrm{x}$ ray irradiation, hormone treatment and temperature shock methods have been developed. Broadly they can be divided into two groups:
Monohaploids or Monoploids: As the name suggest they contains only one basic set of chromosome. They are derived from diploid species e.g. rice, maize etc.

Polyhaploids: Although they contains the gametophytic set of chromosome, but the basic set of chromosome is more than one e.g. wheat haploids contains $3 \mathrm{X}$ basic set of chromosome.

Haploid production through anther culture, microspore culture or pollen culture i.e. which uses male gamete is called as androgenesis while those which uses female gametes e.g. ovule is called as gynogenesis. The basic principle is to stop the development of immature gametic cell into a gamete and force it to develop into a haploid plant. In the year 
1922, Blakeslee et al., reported first about haploid in Datura stramonium. In vitro anther culture was practiced by Guha and Maheshwari (1964) in Datura stramonium. Bourgin and Hitsch (1967) obtained the first full-fledged haploid plants from Nicotiana tabacum. Thereafter, much progress has been made in the anther cultures of wheat, rice, maize, pepper and a wide range of economically important species.

Parthenogenesis, pseudogamy and wide hybridization were used to produce haploid embryos under in vivo condition. The haploid embryo must rescue through embryo rescue techniques and cultured further to produce haploid and subsequently chromosome doubling was done to get doubled haploids. Androgenesis (anther and microspore culture) and gynogenesis (ovary and ovule) were used for haploid production, preferably androgenesis is used.

Haploid production in barley was practiced by wide hybridization; cultivated barley was crossed with wild relative Hordeum bulbosum. Chromosomes from Hordeum bulbosum were selectively eliminated during early seed development stage. This is also known as bulbosum technique (Kasha et al., 1974). Percentage of haploid seeds was very low as compare to hybrids when tobacco (Nicotiana tabacum) was crossed with Nicotiana africana. It is an alternative method for haploid production other than anther culture in tobacco.

The haploids accessibility has extraordinary implication for genetic enhancement of fruit trees where breeding is tricky due to highly heterozygous nature and long generation intervals along with parthenocarpy and selfincompatibility in fruit trees (Rajasekaran and Mullins, 1979). The chromosomes of haploids can be doubled to achieve homozygous diploids. This practice can be significant with
Annona species such as $A$. squamosa and $A$. cherimola, where recessive genes are masked by dominant genes. Nair et al., (1983) showed that haploid plants from A. squamosa could be regenerated from anther callus on $\mathrm{N}$ medium.

The number of anthers cultured in vitro had a distinct effect on production of callus. When grown in groups they seem to give positive response. The anthers required an initial dark period (7-10 days depending on the species) and a high sucrose medium (6\%) followed by light (18 hours of 1000 lux) and lowered sucrose levels. $\mathrm{N}$ medium is the most preferred medium for anther culture, it may be supplemented with low level of sucrose and IAA. For regeneration, anther calli needs to be subcultured onto two different media. The first one was $\mathrm{N}$ medium supplemented with low level of sucrose, BAP and NAA, and the second was the same medium but IAA replacing NAA. High BAP/IAA promotes adventitious shoot development. This method has been found to be working in squashes (Nair et al., 1983).

A doubled haploid is produced through chromosome doubling of haploids. Doubled haploid is implicated for plant breeding programme. Pollen, egg cell, anther cell and cells from gametophyte are used for haploid production. The haploids plants are shorter in size and infertile in nature, male and sterile in nature because they are unable to produce pollen or egg due to absence of their homologous pair during meiotic division. For the survival of these haploid the chromosome number must be doubled. The haploids produced from diploid plants known as monoploid and the haploids derived from tetraploids or hexaploids known as polyhaploids. The dihaploids produced from tetraploid crops help in incorporating genome of wild relatives in breeding programme. Six to seven breeding cycle is required to produce 
homozygous line (though they are not fully homozygous, nearer to complete homozygous) but the doubled haploids are the product of one generation of breeding cycle with surely full homozygosity.

The Annona flower is hermaphroditic and exhibits protogynous dichogamy which limiting the level of self-pollination. This necessitates the use of doubled haploids as parents in single or double cross hybrid production. Doubled haploids are capable of advance the effectiveness of hereditary study and breeding in plants. Seventeen homozygous genotypes were achieved by in vitro anther culture of 'Senshu' apple out of which one produced fertile anther and numerous offsprings were developed from the cross between the doubled haploid and 'Prima' apple. Thus, this doubled haploid will be important for breeding and genetic studies.

In case of annual plants conventional breeding methods is comparatively much easier than perennials due to its small size, short juvenile period and short generation cycle but in case of perennial fruits plants the situation is almost opposite and adverse, the fruits plants are highly heterozygous and heterogeneous in nature, large size, long juvenile period (in case of mango the plant go for flowering when its age more than six years), sometimes self-incompatible also causes problem. So it is very much laborious and time taking process to get homozygous line in perennial fruit crops through conventional breeding. So the haploid breeding is the only solution to get homozygous lines from heterozygous perennial fruit plants.

If parent genotype is $\mathrm{Aa}$, then only two type offspring was produced AA and aa in doubled haploid as compare to normal selfing which produced three types of offspring AA, Aa and aa. Adoption behaviour of doubled haploids was as normal as other lines developed through conventional breeding method.

\section{Applications of haploid and double haploid in plant breeding}

\section{Mapping quantitative trait loci}

QTL (Quantitative trait locus) is the locus having many genes, each having additive effect on the traits. But the phenotype is highly influenced by the environment. So it is very difficult to correlate the actual effect of the genes in the phenotype. So many replication trials were practiced in different environment to know the accurate effect of the genes which is a time consuming and laborious job. In these cases DH is the solution to get homozygous for each allele in the QTL. Haploid and doubled haploid populations are used finding markers linked to traits and QTLs through MAS (marker assisted selection) (Forster and Thomas, 2003) and having a reasonable effect on Australian Barley Mapping Project (Langridge and Barr, 2003).

\section{Backcross breeding}

Doubled haploids produced through gametic embryogenesis need only one breeding cycle in case of heterozygous, cross pollinated and self-incompatible parents. Pure line production is quite easy in self-pollinated crop than cross pollinated one. But 6-7 generation selfing is required for both the cases; after that also we didn't get pure line at every loci. Now a day haploid and doubled haploid are the best existing way to get rid of this hectic selfing cycle in case of perennial crops. In perennial fruits crop it is a good way to produce homozygous line. In case of quantitative trait evolution, application of doubled haploid is highly significant. In nine crop species 130 QTL were mapped through DH. In case of annuals more than 280 new 
varieties was developed through different methods of doubled haploids (http://www.scri.sari.ac.uk/assoc/COST851/, Forster and Thomas 2005). In perennial fruit crops DH variety development needs more time than the annual crops due to its long juvenile period compare to annuals. Also regeneration percentage is also low and maintaining them and characterization of them required time. DH was practiced in many fruit cultivar like citrus, papaya, peach and apple (Pooler and Scorza, 1995a, 1995b; Germanà et al., 2000a, 2005; Höfer et al., 2002; Yahata et al., 2005; Vanwynsberhe et al., 2005; Rimberia et al., 2007).

Another advantage of using haploid and doubled haploid is getting gametoclonal variation when the gametes were put in cultural condition. The gametoclonal variation is shown in form of morphological, biochemical and sometime genetic also (Evans et al., 1984; Morrison and Evans, 1987). The Gametoclonal variation is quite informative, variable and good than somaclonal variation because the variations are created by both mitotic and mitotic cell division event.

Mutagenic effect of mutagens is more prominent in haploid compare to diploid cell in case of diploid its having the opportunity to recover the mutagenic affect by dominant allele but in case of haploid there is only one copy of allele whatever the mutation is their its effect is prominent and visible after diplotization. In this case we get variation from recessive mutant allele along with dominant one due to its homozygous nature by chromosome doubling. Many advanced techniques and tissue culture media and condition helps a lot to get standardized protocol to produced $\mathrm{DH}$ and it is practiced in many species (Howland and Hart, 1977; Maluszynsky et al., 2003). Homozygous mutant population was created through doubled haploid is useful for forward and reverse genetics study. Genome mapping, identification of QTL and major genes are the most useful outcome from DHS population (Khush and Virmani, 1996).

\section{Production of homozygous lines}

Homozygous plants can be obtained in a single generation by diploidization of the haploid. This kind of production of stable, homozygous dihaploids $(\mathrm{DH})$ in a single generation equivalent considerably shortens the breeding cycle. Generally, colchicineis recommended to diploidize the pollen plants.

\section{Induction of mutations}

Detection and isolation of recessive mutants in the haploid state and rapid induction of the mutated gene in a homozygous diploid state is a special merit of haploidy in higher plants. Application of mutagenic treatment at the microspore stage, which is a single celled structure, has the added advantage of obtaining solid mutants.

Obtaining new genotypes with alien chromosomes

Interspecific and intergeneric hybridization combined with anther culture techniques, to produce new genotypes with various reconstructed chromosome complements after their chromosome doubling.

\section{Genetic manipulation}

Haploids are utilized in detecting linkages associated with quantitative inherited characters and could be used in calculating recombination values between linked genes.

\section{Cytogenetic research}

Haploids are useful in various cytogenetic research including production of aneuploids, determination of the nature of Ploidy, 
determination of basic chromosome number and evaluation of the origin of chromosomes.

\section{Somatic fusion}

Protoplast of haploid can be used to produce diploid fertile plant with unique combination of valuable character. It saves labour, time and space.

\section{Methods in obtaining haploids and double haploids}

Perrenial fruits crops are highly heterozygous in nature, its took a long time to enter in reproductive stage, also large canopy size is not manageable, so all these things makes its uncomfortable to produce homozygous line, so only one method which can produce homozygous line for these crops is doubled haploids under in vitro condition.

Since 1970 researcher were trying to developed haploids and doubled haploids in perennial fruits crops through androgenesis and gynogenesis, many cases they got failures but many cases they got success too (Ochatt and Zhang 1996; Germanà 2006). Male gamete pollen and female gamete ovule are the actual key players of haploid production because they only got haploid set of chromosome from megaspore mother cell through meiosis. In major cereals and brassica practice of haploid production through wide hybridization, anther culture, ovule and ovary culture is well known (Wedzony et al., 2006).

\section{In vivo methods of haploid or double haploid production}

\section{Development of spontaneous haploids}

In over 100 species the spontaneous haploid was shown but in fruit crop the recovery rate for haploid production is very low (Zhang et al., 1990). In fruit trees spontaneous and low viable haploid plants obtained in apple, pear, peach, plum, apricot, etc., but with very low frequency and are not practically applicable. The production of spontaneous haploids may be due to parthenogenesis or apogamy.

\section{Distant hybridization}

Hybrids can be produced by elimination of one of the parental genomes as a result of distant (interspecific or inter-generic crosses) hybridization.

In Citrus sp. haploid plants were obtained from an interploidy cross between diploids and triploids

\section{Irradiation effects}

In this method ultra violet rays or X-rays may be used to induce chromosomal breakage and their subsequent elimination from pollens and using the irradiated pollen for fertilization to produce haploids in Citrus, Pear, Apple etc.

\section{Chemical treatment}

Certain chemicals (e.g., chloramphenicol, colchicine, nitrous oxide, maleic hydrazide) can induce chromosomal elimination in somatic cells which may result in haploids.

\section{Chromosome elimination}

In this process haploid obtained by selective chromosome elimination that follows certain interspecific pollinations.

\section{Parthenogenesis}

Haploid regeneration through unpollinated female gametophytes is normally depicted as gynogenesis, or haploid parthenogenesis. The method is practically not feasible unless specific markers used for selection. 


\section{In vitro techniques for haploid production}

\section{Androgenesis}

Haploid production from male gamete is most popular and used method. It was reported that haploid and doubled haploid was successfully practiced more than 200 species most of them are belongs to annuals. The success rate is more in solaneace, graminea family compare to leguminasae and perennial woody plants (Dunwell 1986; Sangwan-Norrel et al., 1986; Bajaj 1990; Raghavan 1990; Wenzel et al., 1995). Young plants, grown under optimal conditions of light, temperature and humidity, are suitable for androgenesis.

\section{Anther culture}

The selected flower buds of young plants are surface-sterilized and anthers removed along with their filaments. The anthers are excised under aseptic conditions, and crushed in $1 \%$ acetocarmine to test the stage of pollen development. If they are at the correct stage, each anther is gently separated (from the filament) and the intact anthers are inoculated on a nutrient medium. Injured anthers should not be used in cultures as they result in callusing of anther wall tissue. The anther cultures are maintained in alternating periods of light (12-18 hr.) and darkness (6-12 hrs.) at $28^{\circ} \mathrm{C}$. As the anthers proliferate, they produce callus which later forms an embryo and then a haploid plant.

\section{Pollen (microspore) culture}

Haploid plants can be produced from immature pollen or microspores (male gametophytic cells). The pollen can be extracted by pressing and squeezing the anthers with a glass rod against the sides of a beaker. The pollen suspension is filtered to remove anther tissue debris. Viable and large pollen (smaller pollen do not regenerate) are concentrated by filtration, washed and collected. These pollens are cultured on a solid or liquid medium. The callus/embryo formed is transferred to a suitable medium to finally produce a haploid plant, and then a diploid plant (on colchicine treatment).

\section{Gynogenesis}

Unfertilized egg cells are used for gynogenesis. In case of parthenogenesis the embryo may be haploid or diploid in nature. Haploid induction through gynogenesis is popular in onion and sugarbeet but for other crops it is not preferred due to its low efficiency (Forster et al., 2007).

\section{Diploidizatioim of haploid plants}

Haploids can be diploidized (duplication of chromosomes) to produce homozygous plants. There are mainly two approaches for diploidization.

\section{Colchicine treatment}

Colchicine is very widely used for diploidization of homologous chromosomes. It acts as an inhibitor of spindle formation during mitosis and induces chromosome duplication. There are many ways of colchicine treatment to achieve diploidization for production of homozygous plants.

When the plants are mature, colchicine in the form of a paste is applied to the axils of leaves. Now, the main axis is decapitated. This stimulates the axillary buds to grow into diploid and fertile branches.

The young plantlets are directly treated with colchicine solution, washed thoroughly and replanted. This results in homozygous plants. The axillary buds can be repeatedly treated with colchicine cotton wool for about 2-3 weeks. 


\section{Endomitosis}

Endomitosis is the phenomenon of doubling the number of chromosomes without division of the nucleus. The haploid cells in general are unstable in culture with a tendency to undergo endomitosis. This property of haploid cells is exploited for diploidization to produce homozygous plants. The procedure involves growing a small segment of haploid plant stem in a suitable medium supplemented with growth regulators (auxin and cytokinin). This induces callus formation followed by differentiation. During the growth of callus, chromosomal doubling occurs by endomitosis. This results in the production of diploid homozygous cells and ultimately plants.

\section{Application of diploid production in fruit crops}

Irradiated pollens were used as pollinator to get haploid from ovule through gynogenesis in many fruit crops in Malus domestica (Zhang and Lespinasse, 1991; Höfer and Lespinasse, 1996), Pyrus communis (Sniezko and Visser, 1987; Bouvier et al., 1993), Actinidia deliciosa (Pandey et al., 1990; Chalak and Legave, 1997), Citrus (De Lange and Vincent, 1988; Ollitrault et al., 1996; Froelicher et al., 2007) and Theobroma cacao (Falque et al., 1992). Gamma rays from cobalt 60 were usually used for irradiating the pollen and then fertilization was done followed by immature ovule/embryo culture in in vitro condition, many cases the embryo rescue techniques also used to rescue the immature embryos. In many studies it was observed that irradiated pollen get germinated on stigma, some of them develops germination tube and enter into embryosac but unable to fertilize the egg and polar nuclei causing pseudogamy which induced parthogenic fruit development (Musial and Przywara, 1998). In case of apple parthenogenic fruit development was there after pollinated with irradiated pollen (James et al., 1985; Nicoll et al., 1987 and cacao (Falque 1994).

Pollen from triploid plants were also used for haploid production, chromosome number of the pollen are not exact haploid or diploid due to absence of homologous pair during meiosis or triploid chromosome came in metaphase plate during meiosis. The pollen was germinated but unable to fertilize with egg, the embryo was rescued after pollination under in situ and in vitro condition. In case of citrus haploid was created by crossing diploid female with triploid male (Oiyama and Kobayashi, 1993; Germanà and Chiancone, 2001).

In 1990 Pandey et al., first reported successful haploid in $A$. deliciosa, using gamma irradiated pollen for fertilization, the haploid was generated parthenogenetically from induced unfertilized egg. Cobalt-60 used as radiation source which results pollen germination (through the lethaly irradiated pollen) and parthenogenic embryo development (Chalak and Legave, 1997). Though Pandey et al., (1990) and Freser et al., (1991) were able to produce haploid plants but they were unable to produce fertile dihaploids.

Gynogenesis was successful used to give haploids in kiwifruit (Fraser et al., 1991). When lethally irradiated pollen from normal males and inconstant male were used as pollinator, the offsprings got reduced ploidy level in many genotypes (Pandey et al., 1990). Pollen germination was affected, number of viable seeds were reduced due to low fruit set and poor fruit growth. It was shown that pollen parent genotype influence the quantity and quality of seedling and trihaploids (Chalak and Legave, 1997). Oryzalin was used for doubling the 
trihaploids (Chalak and Legave, 1996). Though papaya is polygamous in nature but here also anther culture was successful. Haploid plantlets were developed from pollen through anther culture under in vitro condition (Litz and Conover, 1978; Tsay and Sue, 1985).

In Citrus clementina Hort. ex Tan. anther culture is popular and been practiced for long time in different cultivar (Nules, SRA 63, and Monreal). Many plantlets were produced through anther culture. Germanà et al., (1996) did microspore culture of different Citrus species (lemon, orange, clementine, sour orange, grapefruit) to seen the effect of microspore culture in several citrus spp. It was seen that many Multi-nucleated structures, small proembryos and pseudobulbils were developed but embryos and plantlets were not obtained. Haploid using gamma rays in citrus was first reported by Karasawa (1971).

Germanà et al., (2006) evaluated the responses of nine local cultivars for anther culture and of them four cultivars (El Buenet, Marchetto, Peluche and Sanfilippara) were subsequently selected due to their positive response. The cellular changes promoted in the in vitro cultured anthers have been characterized through microscope analysis and show the presence of pollen-derived multi-cellular structures that indicate pollen re-programming.

Zhang and Lespinasse (1988) used unpollinated ovaries and ovules to induce in vitro gynogenesis but no plantlets were obtained in apple. Irradiated pollen was used to pollinate many cultivars and parthenogenetically the fruits were set. The immature embryos were rescued under in vitro condition and Haploid plantlets were regenerated. Dose of irradiation did not affect the pollen viability and in vitro pollen germination but it affect the fruit set and number of viable seeds. The number of viable seeds, empty seed and seed with only endosperm were depend on female genotype (Zhang et al., 1987; Zhang 1988; Zhang and Lespinasse 1991; Zhang et al., 1992; De Witte and Keulemans 1994; Verdoodt et al., 1998; James et al., (1985) and Nicoll et al., (1987)).

Zhang and Lespinasse (1991) studied that normal double fertilization was hampared by irradiated pollen in apple, which can induce or suppress the parthenogenic fruit development. They studied and suggested that following factor induce better parthenogenesis: (1) irradiation doses to pollen should be of 200 and $500 \mathrm{~Gy}$; (2) the fruits must collected 3 months after pollination; (3) cold treatment $\left(3^{\circ} \mathrm{C}\right)$ should be given to the embryos for 2 months before culture in in vitro culture condition. (4).

Immature embryos should be cultured in in vitro culture condition. Many researcher worked on anther culture of apple, they succeeded with haploid embryos and plantlets through androgenesis tough the induction rete was genotype dependent and rate of induction was very low (Fei and Xue, 1981; Xue and Niu, 1984). Effect of genotype was higher on in vitro pollen embryogenesis compare to irradiated pollen induce in situ parthenogenesis (Zhang and Lespinasse, 1991; Höfer and Lespinasse, 1996).

Mulberry is a dioecious plant so homozygous plants are never produced through selfing. It was studied that anther culture was not successful in mulberry to get haploids (Sethi et al., 1992; Jain et al., 1996), but gynogenesis was successful it was seen that un-pollinated ovaries were converted to haploid plantlets through gynogenesis in Morus alba L.Cv.K-2 (Dennis and Thomas et al., 1999). 
In 1996 Haploid $(\mathrm{n}=\mathrm{x}=11$ ) was developed in banana (Musa acuminate, AA) through anther culture by Kerbellec and successful plant regeneration was observed. In 2003, Assani et al., developed 41 haploid plants of Musa balbisiana banana (BB) through anther culture.

Microspore culture was practiced in two olive cultivars (Arbequina and Picual) by Bueno et $a l ., 2004$ and it was resulted in to sporophytic division of the microspore and multi-nucleate microspores development.

In 2006 Germanà et al., were able to produced multi-cellular structures and calli from microspore culture in two Sicilian olive cultivars, Nocellara Messinese and Tonda Iblea.

Harn and Kim (1972) were able to produce calli through androgenesis of apricot anther. Calli and nodular structures were developed from cultivar 'Harcot' through anther culture by Peixe et al., (2004) and its ploidy level was also checked by flow cytometry. They studied the effect of different temperature as pretreatment.

Haploid callus was developed in sweet cherry through anther culture by many researchers. (Seirlis et al., 1979; Höfer and Hanke 1990), but haploid plantlets was not developed further through androgenesis. In 2003 Höfer and Grafe studied that immature embryos were developed from sweet cherry (Prunus avium L.), cultivar 'Altenburger' when it pollinated with irradiated pollen. The fruits were developed through parthenogenesis then this immature embryo were cultured and it was converted to cotyledon type structure further four homozygous line was developed from it. The irradiation dose did not affect the pollen germination but it reduced the fruit set. The maternal origin of the calli was proved by isozyme study.
In 2000, Peixe et al., studied the pollen viability in cv. "Stanley" after different dose of gamma irradiation. These irradiated pollens were used to pollinate a European plum (Prunus domestica L.), cv. "Rainha Clàudia Verde". It was seen that abnormal embryo and $2 \mathrm{n}$ endosperm was developed with 200 Gy irradiated pollen and haploid was induced parthenogenetically but they differentiated up to heart shape embryo. Many plants were obtained when the 100 Gy irradiated pollens were used as pollinator though the plant phenotype was abnormal and all of them were hexaploids in nature as their mother.

Hammerschlag (1983) practiced anther culture of peach (Prunus persica L. Batsch) and were able to produced haploid $(1 \mathrm{x}=1 \mathrm{n}=$ 8) callus but no plantlets were obtained. Through androgenesis haploids plants were developed spontaneously in peach by many researchers (Pratassenja 1939; Hesse 1971; Seirlis et al., (1978). Pooler and Scorza (1995a, 1995b), observed that unreduced gametes were produced in haploid trees. Scorza and Pooler (1999) studied that yield of DHs derived F1 hybrid is similar to standard cultivars.

Three cultivars ('Conference', 'Doyenné du Comice' and 'Gieser Wildeman') of pear was pollinated by irradiated pollen of 'Bonne Louise d'Avranches' which leads to fruit set parthenogenetically. Endosperm development was observed in that fruits but no embryo development was reported (Sniezko and Visser, 1987). In 1993, Bouvier and his coworker studied on induction of parthenogenesis in three cultivars (Doyenné du Comice, Williams and Harrow Sweet) via seedling selection and irradiated pollen. It was observed that only twelve seedlings were haploid (via chromosome counting) among 10,000 seedling. In 2002, Kadota et al., developed. Two embryos through anther culture of pear cv. Le Lectier, but they are 
unable to produced plantlets and origin of haploids was not studied. After that it was studied that dormancy of embryo must broken through some treatment to get plantlets. In pear and apple it was shown that a cold treatment for several weeks was required to break their embryo dormancy. Then only they was able to produced regenerates producing weak shoots (Kadota et al., 2002). Oryzalin (200-300 $\mu \mathrm{M}$ ), was used for chromosome doubling and to get DHs in in vitro condition and ploidy level was measured by flow cytometry (Bouvier et al., 2002). Homozygosity and maternal origin of pear calli and plantlets was assessed by Isozyme analyses and microsatellites (SSRs) study (Bouvier et al., 2002).

In 2002 Kadota et al., developed embryos from cultivar Gold Nijisseiki Shinko through anther culture, though no plantlets were obtained from the experiment. Kadota and Niimi (2004) developed triploid plantlets via androgenesis in cultivar Shinko. In 2004 Kadota and Niimi reported effect of activated charcoal to induced anther culture in Japanese pear.

In 1992 Falque et al., studied the effect of gamma radiation in pollen viability and its germination. It was shown that viability and germination was not affected by the gamma irradiation dose but fruit set through parthenogenesis was affected. Irradiations with more than 100 gy on pollen were unable to induced fruit set and ultimately no haploid was obtained from the experiment. In 1994 Falque irradiated the pollens less than 100 gy and used for pollination but no success was there.

Androgenesis is quite popular in grapevine from long ago, haploid calli was produced through anther culture was reported by many researchers (Gresshoff and Doy, 1974. Kim and Peak, 1981 and Cersosimo, 1986) haploid was produced via anther culture in grapevine by Zou and Li (1981). Haploid plantlets were produced through anther culture by many researchers (Rajasekaran and Mullins, 1979; Bouquet et al., 1982. Hirabayashi and Akihama, 1982 and Mauro et al., 1986). It was seen that diploid somatic embryogenic cultures was established by employing anther culture (Mauro et al., 1986). Effect of media composition and culture condition was studied to improve anther induction in grapevine (Rajasekaran and Mullins, 1979). In 1992 Altamura and his co corker did histological study of Vitis rupestris du Lot microspores during androgenesis of the anthers in in vitro condition.

Looking at the drawback and limited applicability of breeding programs in fruit crop many activities such as QTL mapping, attaining homozygosity is hindered. Haploid and double haploid production is an alternative methodology to overcome the limitation of the breeding. But standardizing the tissue culture protocol protocol for this is an uphill task for the plant researchers which need to be taken care of. As most of the fruit crop releases phenolics during culture affecting their growth and even sometimes the culture died also. So, for future developing standard protocol remains a challenge.

\section{References}

Altamura MM, Cersosimo A, Majoli C, Crespan M (1992) Histological study of embryogenesis and organogenesis from anthers of Vitis rupestris du Lot cultured in vitro. Protoplasma 171: 134-141, 258 M.A. Germanà.

Assani A, Bakry F, Kerbellec F, Haicour R, Wenzel G, Foroughi-Wehr B (2003) Production of haploids from anther culture of banana [Musa balbisiana (BB)]. Plant Cell Rep 21: 511-516.

Bajaj YPS (1990) In vitro production of haploids and their use in cell genetics and 
plant breeding. In: Bajaj YPS (ed) Biotechnology in Agriculture and Forestry: Haploids in Crop Improvement. Berlin: Springer, Vol. 12. Part I. pp. 1-44. Blakeslee AF, Belling J, Farnham ME, Bergner AD (1922) A haploid mutant in the Jimson weed, Datura stramonium. Science 55: 646-647.

Bouquet AB, Piganeau B, Lamaison AM (1982) Influence du génotype sur la production de cals, d'embryons et de plantes entières par cultures d'anthères in vitro dans le genre Vitis. CR Acad Sci Paris 259: 569574.

Bouvier L, Guérif P, Djulbic M, Durel CE, Chevreau E, Lespinasse Y (2002) Chromosome doubling of pear haploid plants and homozygosity assessment using isozyme and microsatellite markers. Euphytica 123: 255-262.

Bouvier L, Zhang YX, Lespinasse Y (1993) Two methods of haploidization in pear, Pyrus communis L.: Greenhouse seedling selection and in situ parthenogenesis induced by irradiated pollen. Theor Appl Genet 87: 229-232.

Bueno MA, Pintos B, Prado MJ, Gomez A, Manzanera JA (2004) Androgenesis: A tool for woody plant breeding. Rec Devel Genet Breed 1: 365-383.

Cersosimo A (1986) Coltura in vitro di antere in Vitis sp. (I contributo). Rivista di Viticoltura e di Enologia di Conegliano 39(12): 520-531.

Chalak L, Legave JM (1997) Effects of pollination by irradiated pollen in Hayward kiwifruit and spontaneous doubling of induced parthenogenetic trihaploids. Sci Hort 68: 83-93

De Lange JH, Vincent AP (1988) Studies on Citrus pollination using gamma irradiated pollen. S Afr J Bot 54: 257-264.

De Witte K, Keulemans J (1994) Restriction of the efficiency of haploid plant production in apple cultivar 'Idared', through parthenogenesis in situ. Euphytica 77: 141-146.

Dennis Thomas T, Bhatnagar AK, Razdan MK, Bhojwani SS (1999) A reproducible protocol for the production of gynogenic haploids of mulberry, Morus alba L. Euphytica 110: 169-173.

Dunwell JM (1986) Pollen, ovule and embryo culture, as tools in plant breeding. In: Withers LAP, Alderson G (eds) Plant Tissue Culture and Its Agricultural Applications. London: Butterwoorths, pp. 375-404.

Evans DA, Sharp WR, Medina-Filho HP (1984) Somaclonal and gametoclonal variation. Am J Bot 759-774.

Falque M (1994) Pod and seed development and phenotype of the M1 plants after pollination and fertilization with irradiated pollen of cacao (Theobroma cacao). Euphytica 75(1-2): 19-25.

Falque M, Kodia AA, Sounigo O, Eskes AB, Charrier A (1992) Gamma-irradiation of cacao (Theobroma cacao) pollen: Effect on pollen grain viability, germination and mitosis and fruit set. Euphytica 64: 167172.

Fei KW, Xue GR (1981) Induction of haploid plantlets by anther culture in vitro in apple. cv. "Delicious". Sci Agric Sin 4: 41-44.

Forster BP, Herberle-Bors E, Kasha KJ, Touraev A (2007). The resurgence of haploids in higher plants. Trends Plant Sci 12(8): 368-375.

Forster BP, Thomas WTB (2005) Doubled haploids in genetics and plant breeding. Plant Breed Rev 25: 57-88.

Fraser LG, Harvey CF, Kent J (1991) Ploidy manipulations of kiwifruit in tissue culture. Acta Hort 297: 109-114

Froelicher Y, Bassene JB, Jedidi-Neji E, Dambier D, Morillon R, Bernardini GG, Costantino G, Ollitrault P (2007) Induced parthenogenesis in mandarin for haploid production: Induction procedures and genetic analysis of plantlets. Plant Cell Rep 26: 937-944.

Germanà MA (2006) Doubled haploid production in fruit crops. Plant Cell Tiss Org Cult 86: 131-146.

Germanà MA, Chiancone B (2001) Gynogenetic haploids of Citrus after in 
vitro pollination with triploid pollen grains. Plant Cell Tiss Org Cult 66: 5966.

Germanà MA, Chiancone $\mathrm{B}$, Lain $\mathrm{O}$, Testolin $\mathrm{R}$ (2005) Anther culture in Citrus clementina: A way to regenerate trihaploids. Aust J Agric Res 56: 839-845.

Germanà MA, Crescimanno FG, Reforgiato G, Russo MP (2000a) Preliminary characterization of several doubled haploids of Citrus clementina cv. Nules. In: Goren R, Goldschmidt EE (eds) Proceedings of the First International Symposium on Citrus Biotechnology. Eilat, Israel. Acta Horticulturae 535, 183 190.

Germanà MA, Scarano MT, Crescimanno FG (1996) First results on isolated microspore culture of Citrus. Proc Inter Soc Citriculture (South Africa). 2: 882 885.

Gresshoff PM, Doy CH (1974) Derivation of a haploid cell line from Vitis vinifera and the importance of the stage of meiotic development of anthers for haploid culture of this and other genera. $\mathrm{Z}$. Pflanzenphysiol 73: 132-141.

Guha S, Maheshwari SC (1964) In vitro production of embryos from anthers of Datura. Nature 204: 497-498.

Hammerschlag FA (1983) Factors influencing the frequency of callus formation among cultivated peach anthers. HortScience 18: 210-211.

Harn C, Kim MZ (1972) Induction of callus from anthers of Prunus armeniaca. Korean J Breed4: 49-53.

Hirabayashi T, Akihama $\mathrm{H}$ (1982) In vitro embryogenesis and plant regeneration from the anther derived callus of Vitis. In: Fujiwara A (ed) Plant Tissue Culture. Tokyo: Maruzen, pp. 547-548.

Höfer M, Gomez A, Aguiriano E, Manzanera JA, Bueno MA (2002) Analysis of simple sequence repeat markers in homozygous lines in apple. Plant Breed 121: 159-162.

Höfer M, Grafe Ch (2003) Induction of doubled haploids in sweet cherry (Prunus avium L.). Euphytica 130: 191-197.
Höfer M, Hanke V (1990) Induction of androgenesis in vitro in apple and sweet cherry. Acta Hort 280: 333-336

Höfer M, Lespinasse Y (1996) Haploidy in apple. In: Jain SM, Sopory SK, Veilleux RE (eds) In Vitro Haploid Production in Higher Plants. Dordrecht: Kluwer, Vol. 3, pp. 259-274.

Howland GP, Hart RW (1977) Radiation biology of cultured plant cells. In: Reinert J, Bajaj YPS (eds) Applied and Fundamental Aspects of Plant Cell, Tissue, and Organ Culture. Berlin/Heidelberg/New York: Springer. pp. 732-756

Jain AK, Sarkar A, Datta RK (1996) Induction of haploid callus and embryogenesis in vitro cultured anthers of Mulberry (Morus indica). Plant Cell Tiss Org Cult 44: 143147.

James DJ, Passey AJ, Mackenzie KAD, Menhinick EC (1985) The effect of pollen irradiation on the development of the post-fertilization ovule of apple (Malus pumilia Mill.). In: Chapman et al., (eds) Experimental Manipulation of Ovule Tissue. London: Longman, pp. 210-224.

Kadota M, Han DS, Niimi Y (2002) Plant regeneration from anther-derived embryos of apple and pear. HortScience, 37(6): 962-965.

Kadota M, Niimi Y (2004) Production of triploid plants of Japanese pear (Pyrus pyrifolia Nakai) by anther culture. Euphytica 138: 141-147.

Karasawa K (1971) On the occurrence of haploid seedlings in Citrus natsudaidai Hayata. Bull. Sakushingakuin Junior Col Woman 1: 1-2.

Kasha KJ (ed) (1974) Haploids in Higher Plants: Advances and Potential, Canada: University of Guelph Press, p. 421.

Khush GS, Virmani SS (1996) Haploids in plant breeding. In: Jain SM, Sopory SK, Veilleux RE (eds) In Vitro Haploid Production in Higher Plants, Dordrecht: Kluwer, Vol. 1, pp. 11-33.

Kim SK, Peak KY (1981) Study on anther culture of grape. 1. Varietal differences in 
callus formation. J Korean Soc Hort Sci 22(2): 89-91.

Litz RE, Conover RA (1978) Recent advances in papaya tissue culture. Proc Florida State Hort Soc 91: 180-182.

Maluszynsky M, Kasha KJ, Szrejko I (2003) Published protocols for other crop plant species. In: Maluszynsky M, Kasha KJ, Forster BP, Szaejko I (eds) Doubled Haploid Production in Crop Plants: A Manual FAO-IAEA. Dordrecht: Kluwer, pp. 309-335.

Mauro MC, Nef G, Fallot J (1986) Stimulation of somatic embryogenesis and plant regeneration from anther culture of Vitis vinifera cv. Cabernet Sauvignon. Plant Cell Rep 5: 377-380

Morrison RA, Evans DA (1987) Gametoclonal variation. Plant Breed Rev 5: 359-391.

Musial K, Przywara L (1998) Influence of irradiated pollen on embryo and endosperm development in kiwifruit. Ann Bot 82: 747-756.

Nair S, Gupta PK, Mascarenhhas AS (1983) Haploid plants from in vitro anther culture of Annona squamosa L. Plant Cell Rep 2: 198-200.

Nicoll MF, Chapman GP, James DJ (1987) Endosperm responses to irradiated pollen in apples. Theor Appl Genet 74: 508-515.

Ochatt SJ, Zhang YX (1996) In vitro haploidization of fruit trees. In: Jain S, Sopory SK, Veilleux RE (eds) In Vitro Haploid Production in Higher Plants. Dordrecht: Kluwer, Vol. 3, pp. 193-210

Oiyama II, Kobayashi S (1993) Haploid obtained from diploid $\mathrm{X}$ triploid crosses of Citrus. J Jpn Soc Hort Sci 62(1): 8993.

Ollitrault P, Allent V, Luro F (1996) Production of haploid plants and embryogenic calli of clementine (Citrus reticulata Blanco) after in situ parthenogenesis induced by irradiated pollen. Proc Int Soc Citric South Africa, 2: 913-917.

Pandey KK, Przywara L, Sanders PM (1990) Induced parthenogenesis in kiwifruit (Actinidia deliciosa) through the use of lethally irradiated pollen. Euphytica 51: $1-9$.

Peixe A, Barroso J, Potes A, Pais MS (2004) Induction of haploid morphogenic calluses from in vitro cultured anthers of Prunus armeniaca cv. 'Harcot'. Plant Cell Tiss Org Cult 77: 35-41.

Peixe A, Campos MD, Cavaleiro C, Barroso J, Pais MS (2000) Gamma-irradiated pollen induces the formation of $2 \mathrm{n}$ endosperm and abnormal embryo development in European plum (Prunus domestica L., cv. "Rainha Clàudia Verde"). Sci Hort 86: 267-278

Pooler MR, Scorza R (1995a) Aberrant transmission of RAPD markers in haploids, doubled haploids, and F1 hybrids of peach: Observations and speculation on causes. Sci Hort 64: 233241.

Pooler MR, Scorza R (1995b) Occurrence of viable eggs in haploid peach. Fruit Varieties J, 49(4): 239-241.

Pratassenja GD (1939) Production of polyploid plants, haploid and triploids in Prunus persica. Camp. Rend. Acad. Sci. (Doklady) URSS, 22: 348-351

Raghavan V (1990) From microspore to embryo: Faces of the angiosperm pollen grain. In: Nijkamp HJJ, van der Plas LH, $\mathbf{J}$ van Hartrigik (eds) Progress in Plant Cellular and Molecular Biology. I.A.P.T.C., Dordrecht: Kluwer, pp. 213221.

Rajasekaran K, Mullins MG (1979) Embryos and plantlets from cultured anthers of hybrid grapevines. J Exp Bot 30: 399407.

Rimberia FK, Adaniya S, Ishimine Y, Etoh T (2007) Morphology of papaya plants derived via anther culture. Sci Hort 111: 213-219.

Sangwan-Norrel BS, Sangwan RS, Pare J (1986) Haploïdie et embryogenèse provoquée in vitro. Bull Soc Bot Fr 133, Actual Bot 4: 7-39.

Scorza R, Pooler MR (1999) Growth and yield of F1 hybrid peaches developed from 
doubled haploids. HortScience 34(5): 928-931.

Seirlis G, Mouras A, Salesses G (1979) Tentatives de culture in vitro d'anthères et de fragments d'organes chez Prunus. Ann Am Plant 29: 145-161.

Sethi M, Bose S, Kapur A, Rangaswamy NS (1992) Embryo differentiation in anther cultures of mulberry. Indian $\mathbf{J}$ Exp Biol 30: $146-148$.

Sniezko R, Visser T (1987) Embryo development and fruit-set in pear induced by untreated and irradiated pollen Euphytica 1: 287-294.

Tsay HS, Sue CY (1985) Anther culture of papaya (Carica papaya L.). Plant Cell Rep 4: 28-30.

Vanwynsberhe L, De Witte K, Coart E, Keulemans J (2005) Limited application of homozygous genotypes in apple breeding. Plant Breed 124: 399-403.

Verdoodt L, Van Haute A, Goderis IJ, De Witte K, Keulemans J, Broothaerts W (1998) Use of the multi-allelic selfincompatibility gene in apple to assess homozygosity in shoots obtained through haploid induction. Theor Appl Genet 96: 294-300.

Wedzony M, Zur I, Golemiec E, Szechin'skaHebda M, Dubas E (2006) Progress in doubled haploid technology. Euphytica DOI: $10.1007 / \mathrm{s} 10681-006-9241-1$

Wenzel G, Frei U, Jahoor A, Graner A, Foroughghi-Wehr B (1995) Haploids - an integral part of applied and basic research. In: Terzi M et al., (eds) Current Issues in Plant Molecular and Cellular Biology. Dordrecht: Kluwer, pp. 127135.
Xue GR, Niu JZ (1984) A study on the induction of apple pollen plants. Acta Hort Sin 11: 161-164.

Yahata M, Harusaki S, Komatsu H, Takami K, Kunitake H, Yabuya T, Yamashita K, Toolapong P (2005) Morphological characterization and molecular verification of a fertile haploid pummel (Citrus grandis Osbeck). J Am Soc Hort Sci 130(1): 34-40.

Zarsky V, Tupy J, Vagera J (1986) In-vitroculture of apple anther. In: Moet-Henessy Conference Fruit Tree Biotechnology, Moet Henessy, Paris, October, Pp. 75.

Zhang YX, Boccon-Gibod J, Lesinasse Y (1987) Obtention d'embryons de pommier après culture d'anthères. Comptes rendus de l'Académie des Sciences, Serie III 305: 443-448.

Zhang YX, Bouvier L, Lespinasse Y (1992) Microspore embryogenesis induced by low gamma dose irradiation in apple. Plant Breed 108: 173-176.

Zhang YX, Lespinasse Y (1988) Culture in vitro d'ovules non fécondés et d'embryons prélevés 8 jours après pollinisation chez le pommier cultivé (Malus x domestica Borkh.). Agronomie 8: 837-842.

Zhang YX, Lespinasse Y (1991) Pollination with gamma-irradiation pollen and development of fruits, seeds and parthenogenetic plants in apple. Euphytica 54: 101-109.

Zhang YX, Lespinasse Y, Chevreau E (1990) Induction of haploidy in fruit trees. Acta Hort 280: 293-304.

Zou CJ, Li PF (1981) Induction of pollen plants of grape (Vitis vinifera L.). Acta Bot Sin 1: 79-81.

\section{How to cite this article:}

Antara Das, Kuldeep Kumar, Kishor U. Tribhuvan, Swosti Suvadarshni Das and Maneesh Mishra. 2018. Development of Haploid and Double Haploid in Fruit Crops - A Review. Int.J.Curr.Microbiol.App.Sci. 7(05): 2119-2132. doi: https://doi.org/10.20546/ijcmas.2018.705.247 